\title{
EFFECT OF POLLUTED IRRIGATION WATER ON FABA BEAN VARIETIES, SOIL PROPERTIES AND THEIR CONTENTS OF HEAVY METALS
}

Atwa. A. A. E.*; A. S. Antar ${ }^{\star}$ and R. A. I. Abo Mostafa**

* Soils, Water and Environment Research Institute Agric. Res. Center

** Field Crops Research Institute, (A R C)

\begin{abstract}
Two Lyzimeter experiments were conducted at Sakha Agricultural Research Station, Kafr El-Sheikh, Egypt, for two seasons, 2007/2008 and 2008/2009. Lyzimeters $(100 \times 70 \times 90 \mathrm{~cm})$ were filled with clayey soil and irrigated with three water treatments since twenty years ago.

The present study aimed to investigate the effect of irrigation water quality for long-term on productivity of four Faba bean varieties (Sakha 2, Giza 461, Giza 3 and Giza 843). Three irrigation water qualities; Nile water $\left(\mathrm{W}_{1}\right)$, polluted drainage water $\left(\mathrm{W}_{3}\right)$ and mixed water; $\mathrm{W}_{2}\left(50 \% \mathrm{~W}_{1}+50 \% \mathrm{~W}_{3}\right)$ used for irrigation to study its effects on faba bean contents from four heavy metals $\mathrm{Ni}, \mathrm{Cd}, \mathrm{Pb}$ and $\mathrm{Cu}$ and some soil characteristics. A split-plot design with four replicates was used where, water treatments and varieties were allocated to main and sub-plots, respectively.

The obtained results showed that:

- Using poor water quality for irrigation increased ECe, SAR, soluble cations and anions in soil paste extract and DTPA extractable heavy metals in soils $(\mathrm{Cu}, \mathrm{Ni}, \mathrm{Cd}$ and $\mathrm{Pb}$ ) than that of mixed or good water quality.

- Highly significant differences of yield and yield components between faba bean verities were found due to irrigation water treatments and its contents of heavy metals.

- Content of the studied heavy metals were in the following order; roots > leaves > coat of seed $>$ cover of pod $>$ seeds.

- The results showed that Sakha 2 was more tolerant variety to drainage and mixed water and its contents of $\mathrm{Ni}, \mathrm{Pb}$ and $\mathrm{Cu}$ were lower than Giza 3, Giza 843 and Giza 461.

- No significant differences were found between all studied faba bean varieties used for Cd content.

- The content of seed faba bean varieties from heavy metals can be arranged as follow:

With Pb: Sakha 2 = Giza $3<$ Giza $461<$ Giza 843

With Cu: Sakha $2<$ Giza $843<$ Giza $3<$ Giza 461

With Ni: Sakha $2<$ Giza $3<$ Giza $843<$ Giza 461

Keywords: Water quality, productivity, heavy metals, Faba bean varieties, soil characteristics.

\section{INTRODUCTION}

Pollution is defined as any change in physical, chemical or biological conditions of the environment which may harmfully affect the quality of human life including effects upon animals and plants.

The untreated industrial drainage waters contain little or more amount of heavy metals, which may cause enhancement of their level in the Nile and/or agricultural drainage water when they mixed.
\end{abstract}


Atwa. A. A. E. et al.

When water containing these metals as pollutants used for irrigation, it will contaminate and enrich soils and crops which may be risks for human food and animal fooder (Zein et al., 1998).

A recent study showed a remarkable increase in levels of heavy metals in some Egyptian soils (especially soils lies in the extreme North Delta) in addition appreciable amount of these metals are found in vegetation, water bodies and aquatic organisms in western and Middle areas of the Nile delta (El-Sanafawy, 2002).

Use of low quality water in irrigation could be an important consideration when the disposal is being planned in arid and semi arid regions. Using drainage water in irrigation caused high increase in EC and SAR of saturated soil paste extract (Omer et al., 2001). Meanwhile, using drainage water in irrigation significantly increase the total and DTPA extractable heavy metals compared with Nile water (Zein et al., 2002).

Once the ions have been absorbed through the roots or leaves and have been transported to the xylem vessels there is the possibility of movement throughout the whole plants. The rate and extent of movement within plants depend on the metal concerned, the plant organ and the age of plant (Chaney and Giordano, 1977). Mn, Zn, Cd, B, Mo and $\mathrm{Cu}$ were classified as intermediate and $\mathrm{Cr}, \mathrm{Pb}$ and $\mathrm{Hg}$ were translocated to least extent. Faba bean (Vicia faba L.) is the most important legume crop in Egypt, due to its high nutritive value for human food and its role break crop in cereal rotation system. The planted area was about 216.000 feddans in the last five seasons. In northern parts of Egypt the planted faba bean area represent about $85 \%$ of the total planted faba bean area. (El-Galay, Ola et al., 2008).

The objectives of the present work are to assess the effect of irrigation water quality for long-term on productivity, heavy metals contents of Faba bean varieties and some soil characteristics.

\section{MATERIALS AND METHODS}

Two lyzimeter experiments were carried out at Sakha Agricultural Research Station, Kafr El-Sheikh, Egypt, for two seasons 2007/2008 and 2008/2009 to study the effect of irrigation water quality for long -term on the productivity of four faba bean varieties, (Sakha 2, Giza 461, Giza 3 and Giza 843) and the content of their leaves, roots, pod cover, seeds and seed coat of heavy metals; $\mathrm{Pb}, \mathrm{Cd}, \mathrm{Ni}$ and $\mathrm{Cu}$.

The study was conducted in concrete Lyzimeters $(100 \times 70 \times 90 \mathrm{~cm})$ Filled with clayey soil science 1987.

The four faba bean varieties were planted on 15 November in two seasons at 20 plants / Lyzimeter.

Three water treatments were used for irrigation; Nile water $W_{1}$ polluted drainage water $\mathrm{W}_{3}$ and mixed water $\mathrm{W}_{2} ;\left(50 \% \mathrm{~W}_{1}+50 \% \mathrm{~W}_{3}\right)$. Some characteristics of the used irrigation water are presented in Table 1.

The treatments were incorporated in a split -plot design with four replicates. Irrigation treatments and varieties were allocated the main and sub plots, respectively. Phosphorus was applied as super phosphate $\left(15.5 \% \mathrm{P}_{2} \mathrm{O}_{5}\right)$ in one dose before sowing at the rate of $30 \mathrm{Kg} \mathrm{P}_{2} \mathrm{O}_{5} / \mathrm{Fed}$. 
Nitrogen was applied as urea (46.5 N\%) at the rate of $15 \mathrm{Kg} \mathrm{N} / \mathrm{fed}$. in one dose after thinning and potassium fertilizer was added in the form of potassium sulphate $\left(48 \% \mathrm{~K}_{2} \mathrm{O}\right)$ at the rate of $24 \mathrm{~kg} \mathrm{~K}_{2} \mathrm{O} / \mathrm{fed}$. after one month of planting. All other agronomic practices were followed as recommended. Plants were harvested at 15 May. Seed, straw weights in $\mathrm{Kg} / \mathrm{fed}$., number of pods/plant, weight of pods, number of seeds/plant and number of branches were recorded. Representative seed and straw, pods, were collected for analysis, dry aching technique was used for samples digestion as described by Chapman and Pratt (1961). Soil samples were taken from each lyzimeter before planting and after harvesting, for chemical analysis; total soluble salts, soluble cations \& anions in soil paste extract were determined according to Richards (1969). Soil samples were DTPA extracted and Pb, Cd, Ni and $\mathrm{Cu}$ were determined using an Atomic Absorption Spectrophotometer. Soil chemical analysis before sowing and after harvesting (according to Lindsay and Norvell, 1978) are presented in Table (2). Statistical analysis was carried out using Irristat- Software, Computer Program.

Table (1): Chemical characteristics of Nile and drainage water used for irrigation during the two seasons.

\begin{tabular}{|c|c|c|c|c|c|c|c|c|c|c|c|c|}
\hline \multirow{2}{*}{$\begin{array}{c}\text { Irrigation } \\
\text { water }\end{array}$} & \multirow{2}{*}{\begin{tabular}{|c|}
$\mathrm{EC}$ \\
$\mathrm{dS} / \mathrm{m}$ at \\
$25^{\circ} \mathrm{c}$ \\
\end{tabular}} & \multirow[b]{2}{*}{$\mathrm{pH}$} & \multicolumn{4}{|c|}{ Cation meq/L } & \multicolumn{4}{|c|}{ Anion $\mathrm{meq} / \mathrm{L}$} & \multirow[b]{2}{*}{ SAR } & \multirow{2}{*}{$\begin{array}{l}\text { Water } \\
\text { class }\end{array}$} \\
\hline & & & $\mathrm{Ca}^{++}$ & $\mathrm{Mg}^{+2}$ & $\mathrm{Na}^{+}$ & $\mathrm{K}^{+}$ & $\mathrm{CO}_{3}=$ & $\mathrm{HCO}_{3}{ }^{-}$ & $\mathrm{Cl}^{-}$ & $\mathrm{So}_{4}=$ & & \\
\hline Nile water & 0.48 & 7.40 & 1.60 & 1.68 & 1.70 & 0.28 & - & 3.45 & 1.11 & 0.70 & 1.33 & $\mathrm{C}_{2}-\mathrm{S}_{1}$ \\
\hline \begin{tabular}{|l|}
$\begin{array}{l}\text { Drainage } \\
\text { water }\end{array}$ \\
\end{tabular} & 1.98 & 8.30 & 4.80 & 2.43 & 12.07 & 0.60 & - & 4.15 & 1.08 & 4.01 & 34 & $\mathrm{C}_{3}-\mathrm{S}_{2}$ \\
\hline \multirow{2}{*}{\multicolumn{5}{|c|}{ Irrigation water }} & \multicolumn{8}{|c|}{ Heavy metal content $\mathrm{mg} / \mathrm{L}$} \\
\hline & & & & & C & & & & \multirow{2}{*}{\multicolumn{2}{|c|}{$\begin{array}{c}\text { Cu } \\
0.016\end{array}$}} & \\
\hline \multicolumn{5}{|l|}{ Nile } & \multicolumn{2}{|c|}{0.016} & \multicolumn{2}{|c|}{0.016} & & & & 016 \\
\hline \multicolumn{5}{|c|}{ Drainage water } & \multicolumn{2}{|c|}{0.260} & \multicolumn{2}{|c|}{0.260} & \multicolumn{2}{|c|}{0.260} & \multicolumn{2}{|c|}{$\begin{array}{l}0.016 \\
0.260\end{array}$} \\
\hline \multicolumn{5}{|c|}{ Critical limits according FAO (1989) } & & \multicolumn{2}{|c|}{0.200} & \multicolumn{2}{|c|}{0.200} & \\
\hline
\end{tabular}

\section{RESULTS AND DISCUSSION}

Nile and drainage water evaluation:

Chemical characteristics of Nile and drainage water used for irrigation of faba bean varieties are shown in Table (1) According to Richard's classification, Nile water $\mathrm{C}_{2}-\mathrm{S}_{1}$; medium salinity low sodicity (Richards, 1969). While, data of drainage water revealed that the water was in the class of $\left(\mathrm{C}_{3} \mathrm{~S}_{2}\right)$, high salinity and medium sodicity which can not be used for soils with restricted drainage and crop with good salt tolerance should be selected. It can be concluded that Nile water is of good quality and drainage water of poor quality for irrigation. The mixed water will be intermediate between them in relation to its chemical composition. Also data in Table (1) Show that the studied heavy metals $\mathrm{Cd}, \mathrm{Pb}, \mathrm{Ni}$ and $\mathrm{Cu}$ content of drainage water were greater than of Nile water and higher than the critical limits, according to FAO (1989), i.e., 0.01, 5.00, 0.2 and 0.2 for $\mathrm{Cd}, \mathrm{Pb}, \mathrm{Ni}$ and $\mathrm{Cu} \mathrm{mg} / \mathrm{L}$, respectively. The high heavy metal contents in drainage water could be attributed to the pollution sources of industrial and municipal wastes discharged to the drainage system these results are in agreement with these obtained by ElMowelhi et al., (1995). 
Atwa. A. A. E. et al.

Effect of the studied irrigation water qualities on some chemical properties of clay soils:

A- Soil salinity, SAR and soluble ions:

Change in electrical conductivity of soil paste extract $(\mathrm{dS} / \mathrm{m})$ soluble cations; $\mathrm{Ca}^{+2}, \mathrm{Mg}^{+2}, \mathrm{Na}^{+}$and $\mathrm{K}^{+}$(meq/L) and soluble anions; $\mathrm{HCO}_{3}{ }^{-}, \mathrm{Cl}^{-}$and $\mathrm{SO}_{4}^{--}$; (meq/L) are listed in Table (2). Comparing the mean ECe values of the studied soils, before planting and after harvesting, the data show that EC values increased from 4.95, 5.62 and $6.56 \mathrm{dS} / \mathrm{m}$ to $5.05,6.00$ and $7.68 \mathrm{ds} / \mathrm{m}$ as affected by $W_{1}, W_{2}$ and $W_{3}$ water quality treatments, respectively. SAR mean values increased from 5.34 and 6.17 to 5.94 and 6.71 as affected by $\mathrm{W}_{2}$ and $\mathrm{W}_{3}$ water treatment. The obtained data showed also, that utilization of drainage water for irrigation purposes tend to increase soluble cations $\mathrm{Na}^{+}$, $\mathrm{Mg}^{++}, \mathrm{So}_{4}{ }^{-}$and $\mathrm{Cl}^{-}$than before planting. The data also showed that all soluble anions, $\mathrm{Cl}^{-}$and $\mathrm{So}_{4}{ }^{-}$mean values, were higher in soil irrigated with poor quality in harmony with those obtained by Zein et al. (1996).

Table (2): Soil chemical analysis before planting and after harvesting under three irrigation water quality (means of two seasons)

\begin{tabular}{|c|c|c|c|c|c|c|c|c|c|c|c|c|}
\hline Water & Catior & $\mathrm{meq} / \mathrm{l}$ & & & Anio & $\mathrm{meq} / \mathrm{l}$ & & & $\mathrm{ECe}$ & $\mathrm{pH}$ & & SP \\
\hline quality & $\mathrm{Ca}^{++}$ & $\mathbf{M g}^{++}$ & $\mathrm{Na}^{+}$ & $\mathrm{K}^{+}$ & $\mathrm{CO}_{3}$ & $\mathrm{HCO}_{3}-$ & $\mathrm{Cl}^{-}$ & $\mathrm{So}_{4--}$ & $\mathrm{ds} / \mathrm{m}$ & 1:2. & & $\%$ \\
\hline & & & & & & 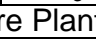 & III & & & & & \\
\hline $\mathrm{W}_{1}$ & 19.5 & 10.6 & 18.98 & $\overline{0.42}$ & & 3.85 & 15.20 & 30.45 & 4.95 & 8.18 & .89 & 5.34 \\
\hline $\mathrm{w}_{2}$ & 22.8 & 11.0 & 21.94 & 0.46 & - & 3.80 & 16.60 & 35 & 5.62 & 8.20 & 5.34 & 5.80 \\
\hline$W_{3}$ & 26.16 & 12.16 & 26.76 & 0.52 & 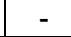 & 3.70 & 22.10 & 80 & 6.56 & 8.25 & & 6.10 \\
\hline & & & & & Afte & har & ting & & & & & \\
\hline $\mathrm{W}_{1}$ & 19.72 & 10.96 & 19.34 & 0.48 & - & 3.90 & 15.60 & 31.00 & 5.05 & 8.10 & 4.95 & 75.40 \\
\hline $\mathrm{W}_{2}$ & 23.42 & 11.32 & 24.76 & 0.50 & - & 3.75 & 17.96 & 38.29 & 6.00 & 8.00 & 5.94 & 75.85 \\
\hline$W_{3}$ & 31 & 13.00 & 31.66 & 0.58 & - & 3.80 & 25.22 & 47.68 & 7.68 & 8.30 & 6.71 & 76.22 \\
\hline
\end{tabular}

B- DTPA- extracted heavy metals from studied soils:

Data in Table (3) show that all values of DTPA extractable heavy metals of soils can be discendingly arranged according to the effect of water treatments as follow: $W_{3}>W_{2}>W_{1}$ before faba bean planting and after harvesting.

It seems that soil content of DTPA-extractable studied heavy metals has followed the sequence $\mathrm{Cu}>\mathrm{pb}>\mathrm{Ni}>\mathrm{Cd}$. This trend was different from that found under using drainage water and mixed water $\mathrm{pb}>\mathrm{Cu}>\mathrm{Ni}>\mathrm{Cd}$. This may be due to that some of available $\mathrm{Pb}$ changed to these findings. The obtained results are in agreement with those of Abou El-Roos et al. (1991) who found that the behaviour of $\mathrm{Cu}$ and pb differ from that of $\mathrm{Cd}, \mathrm{CO}$ and $\mathrm{Ni}$ in soils irrigated with sewage effluent, they added that in $\mathrm{Cd}, \mathrm{Cu}$ and $\mathrm{Ni}$ metals, the percentages held in primary minerals fraction were increased with time on the expense of the percentage of other fractions, especially that organically complexed. Although the studied soils were still beyond the critical levels, it could be reached this point upon the continuous using of polluted drainage water.

Effect of polluted irrigation water on yield and yield components:

Data in Table (4) show that the seed yield (Kg/fed.) of Faba bean were significantly affected with Faba bean varieties. The higher mean seed yields 
(1722.5, 1717.5), (1615.0, 1622.5) and $(1512.5,1480) \mathrm{kg} / \mathrm{fed}$. were obtained with Sakha 2 at $W_{1}, W_{2}$ and $W_{3}$ in the two seasons, respectively.

Table (3): DTPA extractable heavy metal concentrations from 2007 to $2009(\mathrm{mg} / \mathrm{kg})$ before planting and after harvesting faba bean varieties (means of two seasons) as affected by water quality.

\begin{tabular}{|c|c|c|c|c|}
\hline \multirow{2}{*}{ Irrigation water quality } & \multicolumn{4}{|c|}{ Heavy metal content $\mathbf{~ m g} / \mathbf{k g}$ soil } \\
\cline { 2 - 5 } & $\mathbf{C d}$ & $\mathbf{N i}$ & $\mathbf{P b}$ & $\mathbf{C u}$ \\
\cline { 2 - 5 } & \multicolumn{4}{|c|}{ Before planting ( mg/kg soil ) } \\
\hline $\mathbf{W}_{\mathbf{1}}$ & 0.0920 & 1.61 & 3.77 & 5.80 \\
$\mathbf{W}_{\mathbf{2}}$ & 0.1418 & 1.86 & 8.40 & 6.50 \\
$\mathbf{W}_{\mathbf{3}}$ & 0.1620 & 2.23 & 10.40 & 7.1 \\
\hline & \multicolumn{4}{|c|}{ After harvesting ( $\mathbf{~ m g / k g ~ s o i l ~ ) ~}$} \\
\hline $\mathbf{W}_{\mathbf{1}}$ & 0.0940 & 1.82 & 3.7 & 5.9 \\
$\mathbf{W}_{\mathbf{2}}$ & 0.1560 & 2.10 & 8.8 & 6.7 \\
$\mathbf{W}_{\mathbf{3}}$ & 0.1731 & 2.40 & 11.02 & 7.3 \\
\hline
\end{tabular}

Table (4): Effect of irrigation water treatments on yield and yield componentsof the tested Faba bean varieties in two seasons.

\begin{tabular}{|c|c|c|c|c|c|c|}
\hline \multirow{2}{*}{ Varieties } & \multicolumn{3}{|c|}{$\begin{array}{c}\text { First season } \\
\text { Irrigation water }\end{array}$} & \multicolumn{3}{|c|}{$\begin{array}{l}\text { Second season } \\
\text { Irrigation water }\end{array}$} \\
\hline & $\mathrm{W}_{1}$ & $\mathbf{W}_{2}$ & $\mathbf{W}_{3}$ & $\mathrm{~W}_{1}$ & $\mathrm{~W}_{2}$ & $\mathbf{W}_{3}$ \\
\hline & \multicolumn{6}{|c|}{ Seeds kg/fed. } \\
\hline Giza 3 & $1420.00 \mathrm{~d}$ & $1213.8 \mathrm{c}$ & $1174.5 \mathrm{~d}$ & $1440.0 \mathrm{c}$ & $1252.5 \mathrm{c}$ & $1177.5 \mathrm{c}$ \\
\hline Giza 461 & $1640.00 \mathrm{~b}$ & $1123.3 \mathrm{~d}$ & $945.3 \mathrm{~d}$ & $1660.0 \mathrm{~b}$ & $1133.3 \mathrm{~d}$ & $948.00 \mathrm{~d}$ \\
\hline Giza 843 & $1617.50 \mathrm{c}$ & $13685 b$ & $1204.0 \mathrm{~b}$ & $1637.5 \mathrm{~b}$ & $1383.5 \mathrm{~b}$ & $1221.3 b$ \\
\hline \multirow[t]{2}{*}{ Sakha 2} & $1722.50 \mathrm{a}$ & $1615.0 \mathrm{a}$ & $1512.5 \mathrm{a}$ & $1717.5 \mathrm{a}$ & $1622.5 \mathrm{a}$ & $1480.0 \mathrm{a}$ \\
\hline & \multicolumn{6}{|c|}{ Straw kg/fed. } \\
\hline Giza 3 & $1903.8 \mathrm{c}$ & $1701.5 \mathrm{c}$ & $1642.5 \mathrm{~b}$ & $2003.8 \mathrm{~b}$ & $1801.5 \mathrm{~b}$ & $1717.5 \mathrm{~b}$ \\
\hline Giza 461 & $2349.5 \mathrm{a}$ & $2277.5 \mathrm{a}$ & $1962.3 \mathrm{a}$ & $2357.5 \mathrm{a}$ & $2280.0 \mathrm{a}$ & $1967.5 \mathrm{a}$ \\
\hline \multirow{3}{*}{$\begin{array}{l}\text { Giza } 843 \\
\text { Sakha } 2\end{array}$} & $1735.8 d$ & $1510.0 \mathrm{~d}$ & $1460.3 \mathrm{~d}$ & $1745.0 \mathrm{~d}$ & $1512.5 c$ & $1457.5 \mathrm{a}$ \\
\hline & $1932.5 b$ & $1828.5 b$ & $1528.3 \mathrm{c}$ & $1947.5 \mathrm{c}$ & $1830.0 \mathrm{~b}$ & $1525.0 \mathrm{c}$ \\
\hline & \multicolumn{6}{|c|}{ Number of pods/plant } \\
\hline Giza 3 & $5.0 \mathrm{a}$ & $4.3 \mathrm{a}$ & $3.8 \mathrm{a}$ & $5.00 \mathrm{a}$ & $4.25 \mathrm{a}$ & $3.75 \mathrm{a}$ \\
\hline Giza 461 & $4.8 \mathrm{a}$ & $3.3 \mathrm{~b}$ & $3.0 \mathrm{a}$ & $4.75 \mathrm{~b}$ & $3.00 \mathrm{~b}$ & $2.75 \mathrm{~b}$ \\
\hline Giza 843 & $4.3 \mathrm{a}$ & $3.8 \mathrm{ab}$ & $3.3 \mathrm{a}$ & $4.75 \mathrm{~b}$ & $4.00 \mathrm{ab}$ & $3.25 \mathrm{a}$ \\
\hline \multirow[t]{2}{*}{ Sakha 2} & $4.3 \mathrm{a}$ & $3.8 \mathrm{ab}$ & $3.3 \mathrm{a}$ & $4.5 \mathrm{~b}$ & 4.00 & $3.25 \mathrm{a}$ \\
\hline & \multicolumn{6}{|c|}{ Weight of pods (gm) } \\
\hline \multirow{5}{*}{$\begin{array}{l}\text { Giza 3 } \\
\text { Giza 461 } \\
\text { Giza 843 } \\
\text { Sakha 2 } \\
\end{array}$} & $2.74 \mathrm{~b}$ & $2.49 \mathrm{c}$ & $2.35 \mathrm{c}$ & $2.77 \mathrm{c}$ & $2.49 \mathrm{~b}$ & $2.35 c$ \\
\hline & $3.31 \mathrm{a}$ & $2.43 \mathrm{c}$ & $2.20 \mathrm{c}$ & $3.40 \mathrm{~b}$ & $2.40 \mathrm{~b}$ & $2.2 \mathrm{c}$ \\
\hline & $3.63 \mathrm{a}$ & $2.95 \mathrm{~b}$ & $2.78 \mathrm{~b}$ & $3.65 a b$ & $3.3 \mathrm{a}$ & $3.25 \mathrm{a}$ \\
\hline & $3.63 \mathrm{a}$ & $3.35 \mathrm{a}$ & $3.20 \mathrm{a}$ & $3.83 \mathrm{a}$ & $3.25 \mathrm{a}$ & $3.20 \mathrm{a}$ \\
\hline & \multicolumn{6}{|c|}{ Number of seeds /pod } \\
\hline Giza 3 & $2.5 \mathrm{~b}$ & $2.0 \mathrm{~b}$ & $1.8 \mathrm{~b}$ & $3.00 \mathrm{c}$ & $2.25 \mathrm{~b}$ & $1.75 \mathrm{bc}$ \\
\hline Giza 461 & $3.8 \mathrm{a}$ & $2.8 \mathrm{a}$ & $1.8 \mathrm{a}$ & $3.5 b$ & $2.75 \mathrm{ab}$ & $1.5 \mathrm{c}$ \\
\hline Giza 843 & $3.8 \mathrm{a}$ & $3.3 \mathrm{a}$ & $3.0 \mathrm{a}$ & $4.00 a b$ & $3.25 \mathrm{a}$ & $2.75 \mathrm{a}$ \\
\hline \multirow[t]{2}{*}{ Sakha 2} & $4.3 \mathrm{a}$ & $3.3 \mathrm{a}$ & $3.0 \mathrm{a}$ & $4.5 \mathrm{a}$ & $3.25 \mathrm{a}$ & $2.8 \mathrm{a}$ \\
\hline & \multicolumn{6}{|c|}{ Number of branches } \\
\hline Giza 3 & $1.8 \mathrm{a}$ & $1.5 \mathrm{a}$ & $1.5 \mathrm{a}$ & $1.75 \mathrm{a}$ & $1.75 \mathrm{a}$ & $1.5 \mathrm{a}$ \\
\hline Giza 461 & $1.8 \mathrm{a}$ & $1.5 \mathrm{a}$ & $1.3 \mathrm{a}$ & $1.75 \mathrm{a}$ & $1.50 \mathrm{a}$ & $1.25 \mathrm{a}$ \\
\hline Giza 843 & $1.8 \mathrm{a}$ & $1.5 \mathrm{a}$ & $1.5 \mathrm{a}$ & $1.75 \mathrm{a}$ & $1.75 \mathrm{a}$ & $1.5 \mathrm{a}$ \\
\hline Sakha 2 & $2.0 \mathrm{a}$ & $1.8 \mathrm{a}$ & $1.8 \mathrm{a}$ & $2.00 \mathrm{a}$ & $1.75 \mathrm{a}$ & $1.75 \mathrm{a}$ \\
\hline
\end{tabular}

The obtained data show that Sakha 2 variety was the superior in its seed yield for all water quality treatments. In contrast the higher mean of 
Atwa. A. A. E. et al.

straw yields $(2349.5,2357.5),(2277.5,2280)$ and $(1962.3,1967.5) \mathrm{kg} / \mathrm{fed}$. were obtained with Giza 461 variety for all water quality treatments in the two seasons, respectively.

Number of the pods / plant were insignificantly affected with Faba bean varieties under this studies, while weight of the pods/plant were significantly affected by Faba bean varieties. The higher means $(3.63,3.83),(3.35,3.25)$ and $(3.2,3.2) \mathrm{gm}$ were produced from Sakha 2 under $\mathrm{W} 1, \mathrm{~W}_{2}$ and $\mathrm{W}_{3}$, respectively. Followed by $(3.63,3.65),(2.95,3.3)$ and $2.78,3.25) \mathrm{g}$ with Giza 843 Faba bean variety in the first and second season, respectively.

Number of the branches / plant were insignificant affected with Faba bean varieties and water treatments in the two seasons. The highest numbers of seed/pod and weigh of pods ( $\mathrm{g}$ ) were attained by Sakha 2 .

Heavy metals contents:

Data in Table (5) show that the studied heavy metals $\mathrm{Cd}, \mathrm{Pb}, \mathrm{Ni}$ and $\mathrm{Cu}$ content of faba bean plant under drainage water were greatest than that of Nile water and mixed water. This could be attributed to the pollution sources of industrial (oil and soap factory) and municipal wastes discharged to the drainage system. These results are in agreement with those obtained by Zein et al. (2002) and El-Mowelhi et al. (1995).

Table, 5 and Figs from, 1 to 4 illustrate the influence of water quality on the studies heavy metals means concentration in roots, coat seed, pod cover, leaves and seeds. On faba bean varieties especially with irrigated by drainage water $\left(\mathrm{W}_{3}\right)$ were as the following order:

Roots: $\mathrm{Pb}>\mathrm{Ni}>\mathrm{Cu}>\mathrm{Cd}$

Leaves: $\mathrm{Pb}>\mathrm{Cu}>\mathrm{Ni}>\mathrm{Cd}$

Seed coat : $\mathrm{Ni}>\mathrm{Pb}>\mathrm{Cu}>\mathrm{Cd}$

Pod cover: $\mathrm{Ni}>\mathrm{Pb}>\mathrm{Cu}>\mathrm{Cd}$

Seed $: \mathrm{Ni}>\mathrm{Pb}>\mathrm{Cu}>\mathrm{Cd}$

Table (5) reveals the highly significant effects of water quality $\left(\mathrm{W}_{1}, \mathrm{~W}_{2}\right.$ and $\left.\mathrm{W}_{3}\right)$ especially with $\mathrm{Ni}, \mathrm{Pb}$.

The distribution of $\mathrm{Cu}$ within plants is highly variable within roots $\mathrm{Cu}$ is associated mainly with cell wall and its largely mobile.

Dunman et al. (1991) found that the concentration of $\mathrm{Ni}$ in plants, generally, reflects the concentration of the element in the soil, although the relationship is clearly more directly related to the concentration of soluble ions of $\mathrm{Ni}$ and rate replenishment of this mobile pool. As $\mathrm{Ni}$ is easily mobile in plant, berries and seeds are reported to contain elevated Ni concentration (Alina and Pendias et al., 2000).

Cadmium values (Table, 5 ) of seeds indicated that $\mathrm{Cd}$ has the lowest values in all studied heavy metals. This conclusion are in agreement with Alloway (1995) who found that the uptake of $\mathrm{Cd}$ decreased when $\mathrm{pH}$ was increased, faba bean showed a similar response.

Page et al. (1981) found that relative excess of $\mathrm{Cu}, \mathrm{Ni}$ and $\mathrm{Mn}$ can reduce uptake of $\mathrm{Cd}$ by plants. The $\mathrm{Cd}$ in plants is relatively very mobilize, although the translocation of $\mathrm{Cd}$ through the plant tissues may be restricted because $\mathrm{Cd}$ is easily held mainly in exchange sites of active compounds located in the cell walls (Cunningham et al., 1975). 
J. of Soil Sciences and Agricultural Engineering - Vol. 1 (2), February, 2010

5 

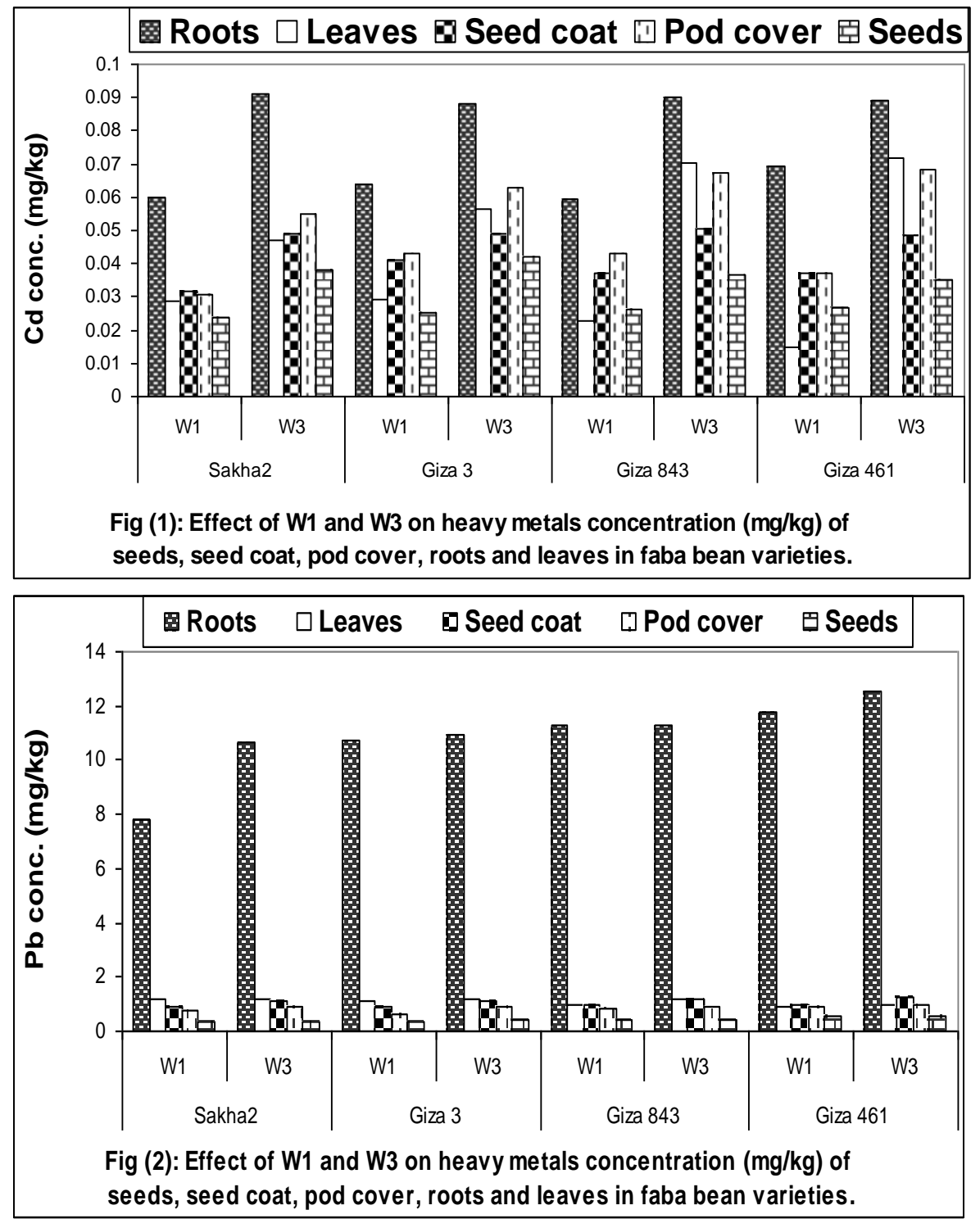

Data in Table (5) indicates that the seed of faba bean varieties generally had the lowest content of studied heavy metals under all water treatments. No significant in Cd for all treatments of water quality and faba bean varieties. Sakha 2 faba been variety had the lowest content of $\mathrm{Pb}, \mathrm{Ni}$ and $\mathrm{Cu}$ under all water treatments. The order of faba bean varieties to concentration of heavy metals decreased as follow:

With Cd : Sakha 2 = Giza $3=$ Giza $843=$ Giza 461

With $\mathrm{Pb}$ : Sakha 2 = Giza $3<$ Giza $461<$ Giza 843

With $\mathrm{Cu}$ : Sakha $2<$ Giza $843<$ Giza $3<$ Giza 461

With Ni : Sakha $2<$ Giza $3<$ Giza $843<$ Giza 461 

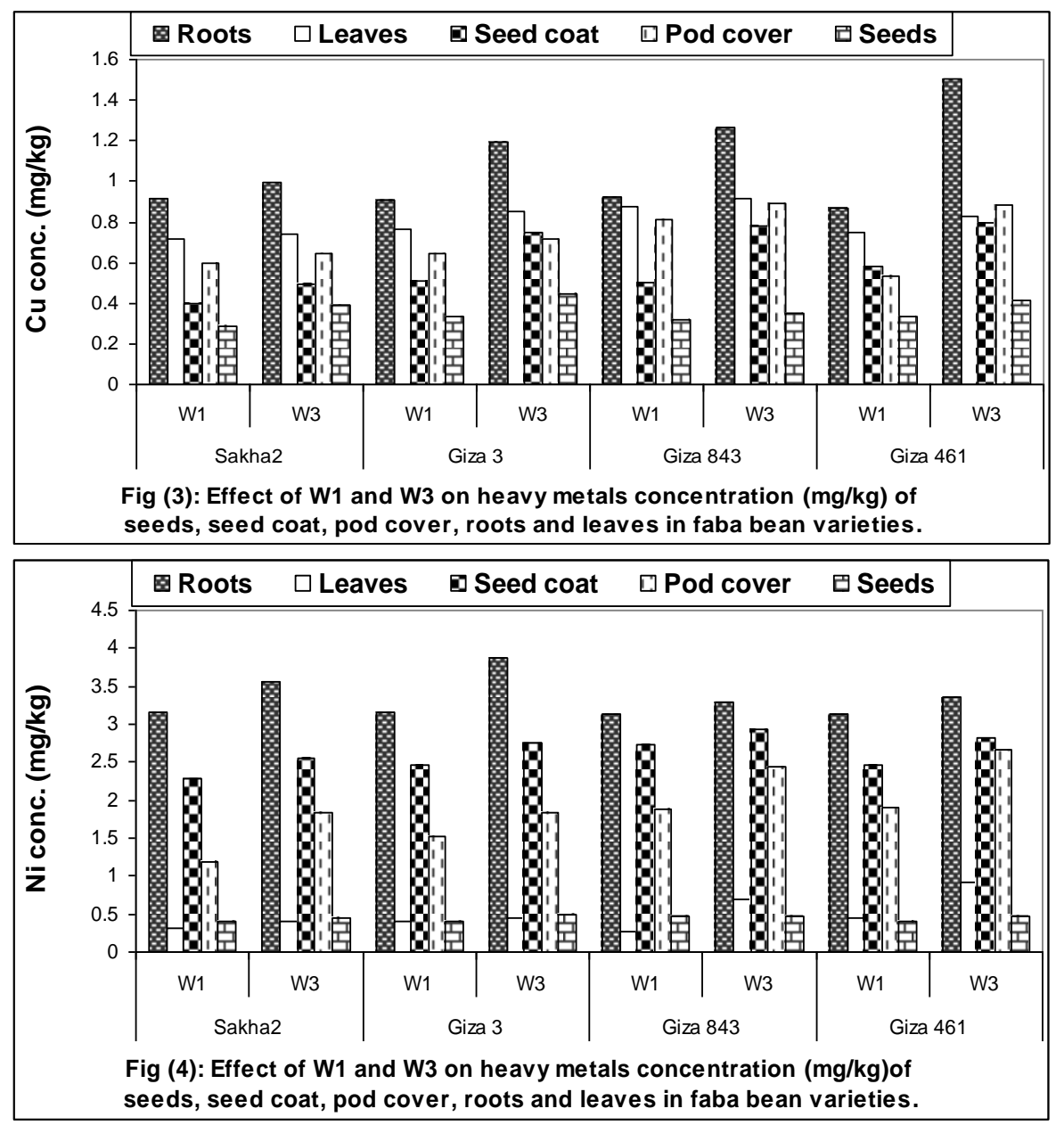

These results very important for classified the common faba bean varieties to various heavy metals polluted soils. From these sequences we can favor one variety in every soil polluted with one element.

These results are in partial agreement with those obtained by Zein et al. (1996) in their study on soybean cultivars. These results may be due to the differences in genetic constitution of the studied genotypes and / or the dilution effect phenomenon. This conclusion is in partial agreement with that of Shalaby et al. (1996) who concluded that increasing of heavy metals concentration in plants may attributed either to the higher amounts of these heavy metals added into the used soil through the applied wastes.

Translocation coefficient from roots to seeds :

Once the ions have been absorbed through the roots and have been transferred to the xylem vessels, there is possibility of movement throughout the whole plant, the rate and extent of movement within plants was studied by, Alloway (1995). The data of heavy metal concentration in seeds, roots, of studied Faba bean varieties and coefficient of their 
Atwa. A. A. E. et al.

translocation (TC) from roots to seed are presented in Table 5 and seed TC was calculated as follow.

Seed TC $=$

Content of heavy metal in seeds $(\mathrm{mg} / \mathrm{kg})$

Content of the same heavy metal in roots $(\mathrm{mg} / \mathrm{kg})$

$x 100$

Data in Table (5) illustrate that the studied heavy metals translocation from roots to seeds can be arranged according to mean values of translocation coefficient in the following decreasing order :

$\mathrm{Cd}>\mathrm{Cu}>\mathrm{Ni}>\mathrm{Pb}$

It shows that $\mathrm{Cd}$ was the largest values of TC while pb was the least in translocation from root to seed in all types of water treatments $\left(W_{1}, W_{2}\right.$ and $\left.W_{3}\right)$. The results are in good agreement with those of Zein et al. (2002) and Chaney and Giordano (1977) who classified pb as one of the least translocated elements with plant. They added that, under conditions of optimal growth, pb precipitates on root cell wall in the insoluble amorphous form. Zhen - Guo Shen et al., (2009). found that application of EDTA ( as an organic conditioner ) to the soil significantly increased the concentrations of $\mathrm{Pb}$ and enhancing pb accumulation in the plants while the $\mathrm{Cu}$ and $\mathrm{Cd}$ and $\mathrm{Ni}$ concentration and translocation coefficient indicate that $\mathrm{Ni}$ values increased due to drainage water treatment than other treatment due to its higher content of polluted drainage water from oil and soap factory ( used Ni catalyst in one processes of manufacturing). The obtained results are in good agreement with ( Zein et al., 2002) and Chancy and Giordano (1977) for heavy metal translocation.

\section{Conclusion}

Considering the previous discussions and conclusions, it seems that there is an obvious need for more research work to be carried out on the risk assessment of heavy metals contaminated soils. As mentioned by Essa and El-Kassas (1999) the danger of distribution wastes by such factories containing high concentration of heavy metals affects the survival in the suffering areas. The safest policy would appear to minimize inputs of heavy metals to soil wherever to save our life and economy and restrict heavy metals bioavailability in the soil - plant animal pathway. Abo El-Naga et al. (1999) and Zien et al.(2009) recommended that attention must be earnestly given to protect the environment and commitments and the latest law issued 1994 in Egypt, must be obligatory under taken for these factories to prevent them from polluting agricultural soil by wastes.

Apart from the roles played by pollution control and soil chemistry, plant breading can make a vital contribution through the selection and utilization of crop genotypes which accumulate the least heavy metals

\section{REFERENCES}

Abo El-Naga, S.A; El-Shinawani, M. M.; El-Swaaby, M.S. and Salem, M.S. (1999). Chemical pollution of soils, water and plants at the industrial area of Helwan city in Egypt. J. Soil Sci. 39 (3): 263. 
Aboulroos, S.A.; Halah, Sh.Sh.; El-kherbawy, M.I. and E.H. Badawy (1991). Fractionation of some heavy metals in soils irrigated with sewage effluents for different years. Egypt. J. Soil Sci. 31 (1), 43.

Alina, K.P. and Pendias, H (2000). "Trace elements in soils and plants". Third edition. BoCa Raton Lond New York Washigton, D.C. P. 413.

Alloway. B.J.t (1995). Heavy metals in soils, $2^{\text {nd }}$ Chapman and Hall London

Chancy, R.L. and Giordano, R.L. (1977). Solis for the management of organic wastes and waste water, In : L.F. Elliot and F.J. Steven son (Eds.) Soil Sci. Soc. Am., Am, Soc. Agron 7 Crop Sci. Soc. Am., Medison. 235-279 (C.F Alloway, 1995).

Chapman, H. D and Pratt, P.E. (1961). Method of analysis for soils, plants and waters. Univ. California; Division of Agric. Science.

Cunningham, L.M.; Collins, F.W. and Hutchinson, T.C. (1975). Physiological and biochemical a speets of cadmium toxicity in soybean, paper presented at Int. Conf. on heavy metals in the Environmental, Toronto P. 97.

Duneman, L., von Wiren, N. Schulz, R. and Marschener, H. (1991). Plant and Soil, 133, 263.

Eissa, A.M. and El-Kasses, H.I. (1996). Impact of heavy metals on soil, plant and water at Abou-Zaabal area. Egypt. J. soil Sci. 39 (2), 211.

El-Galaly, Ola A. M.; R.A.I. Abou - Mostafa; A. M. Nassef and Nagwa, M. A. Mahmoud (2008). Response of two faba bean (Vicia faba L.,) promising lines and Sakha 3 cultivar to different sowing dates and densities J. Agric. Res. Kafr El-Sheikg Univ., 34 (3) : 647-661.

El-Mowelhi, N.M; El-Nasher, B.M. and El-waked, A.F. (1995). Quality aspects of the drainage water of western delta area. Conf. of on farm irrig. And Agro climatology, Cairo, Egypt pp. 638.

El-Sanafawy, Hamida, M. (2002). Geochemical investigation on soil and water on polluted areas in Mid-Nile Delta for environmental assessment. Ph.D Thesis, Fac. Sci. Mansoura Univ., Egypt, p. 248.

FAO (1989). Water quality for agricultural. In R.S. Ayears and D.W. Westcot. Irrigation and Drainage paper 29 Rev. 1, Rome.

Lindsay, W.K. and W.A. Norvall (1978). Development of a DTPA test for zinc, iron, manganese and Copper. Soil, Sci. Soc. Amer. J. Proc, 42 : 421-428.

Omar, E.H.; E.A.E. Gazia, M.A; Ghazy and M.A.A. Abd Allah (2001). Effect of irrigation water quality and sludge application in soil salinity, sugarbeet and canola yield and irrigation efficiencies. Minufiya $\mathrm{J}$. Agric. Res. Vol. 26 No. 6: 1751-1665.

Page, A.L.; Bingham, F.T. and Chang, A.C. (1981). Effect of heavy metalal pollution on plants Vol. 1, $1^{\text {st }}$ lepp, N.W. Applied science, London pp. 72-109.

Richards, L.A. (1969). Diagnosis and improvement of saline and alkali soils. U.S. Dep. Agric, Handbook No. 60.

Shalaby. M.H; Gabran, O.A and Raslan, M.I. (1996). Chemical properties of soils as affected by pollution of different wastes, J. Soil. Sci.36 (1-4) 1. 23.

Zein, F. I.; Hamida M.A. El-Sanafawy; N.I. Jalha and Samia A. Salama (2009). Using canola plants for phytoextracting heavy mateals from soil irrigation with polluted drainage water for Alongterm. J. Agric. Sci. Mansoura Univ., 34 (6): 7309-7323. 
Atwa. A. A. E. et al.

Zein, F.I.; Hegab, O.A and El-Sanafawy, Hamida, M. (1998). Geochemical studies on some polluted soils in Kafr El-Sheikh Governorate. Egypt. J. Agric. Sci. Mansoura Univ., Vol. 23, No. 6, PP. 2887-2918.

Zein, F.I.; Maani, Z. Abou Amou, A.A. El-Leithi and M.M. El-Shami (2002). Effect of polluted irrigation water on some crops and their contents of heavy metals. 1-Wheat. Egypt. J. Soil Sci., 42 No. 1, PP. 139-159.

Zien, F. I; El-Leithi, A.A and Abou Amou, M. Z. (1996). Effect of irrigation with polluted drainage water on clay soils, some crops and their contents of heavy metals, some soybean cultivars. J. Agri-Sci-Mansoura Univ. 21 (10), 3753.

Zhen-Guo Shen, Xiang-Dong Li, Chun-Chun Wang, Huai-Man Chen and Hong Chua (2009). Lead phytoextraction from contaminated soil with high-Biomass plants Species. J. Environ. Qual. 31: 1893-1900.

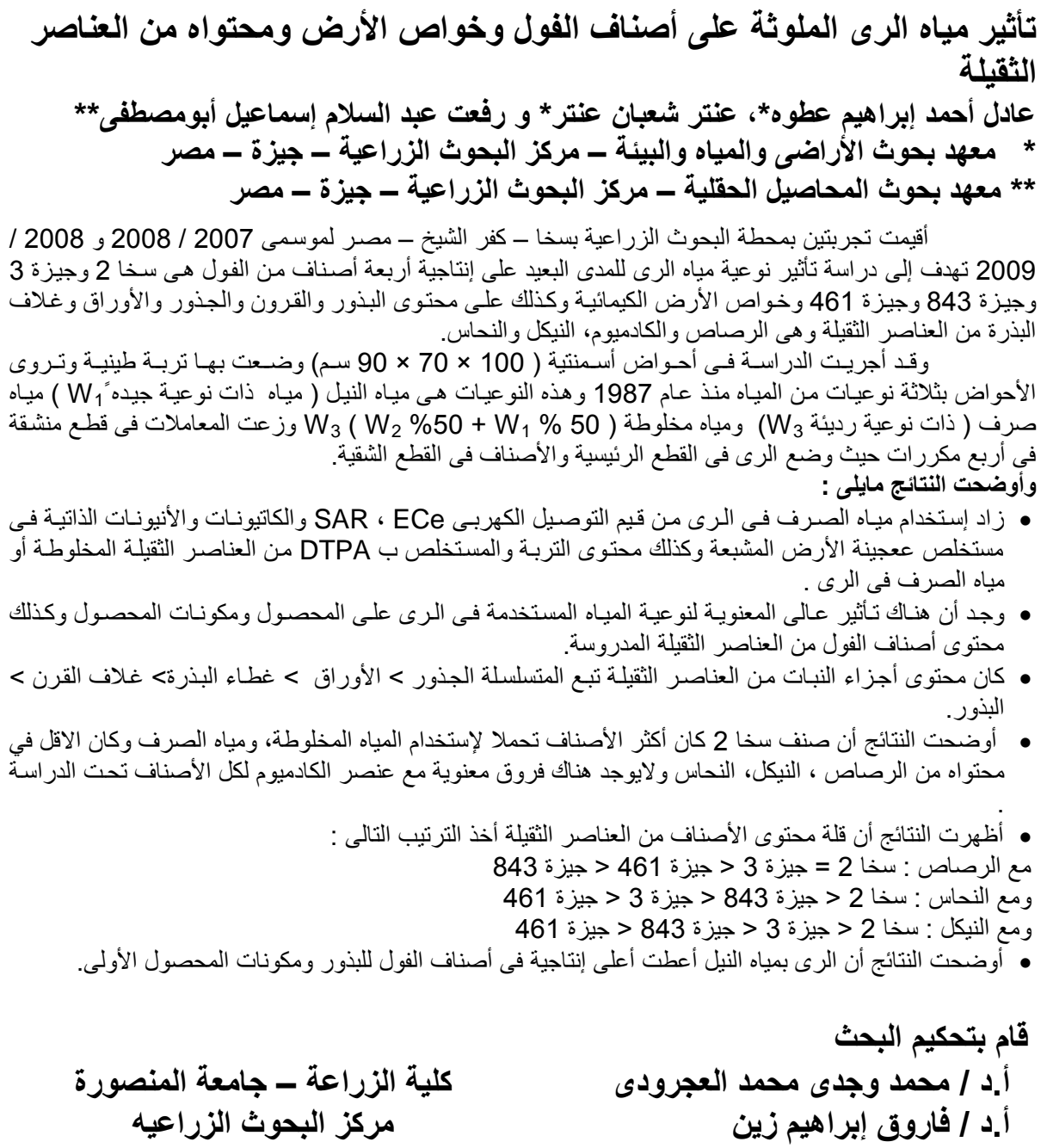

كلية الزراعة - جامعة المنصورة مركز البحوث الزراعيه

قام بتحكيم البحث

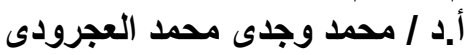

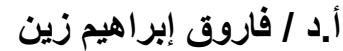


Table (5): Effect of water treatments on heavy metals content $(\mathrm{mg} / \mathrm{kg}$ ) of faba bean varieties (Mean of two seasons).

\begin{tabular}{|c|c|c|c|c|c|c|c|c|c|c|c|c|}
\hline \multirow[b]{2}{*}{ Varieties } & \multicolumn{3}{|c|}{ Cd } & \multicolumn{3}{|c|}{$\mathbf{P b}$} & \multicolumn{3}{|c|}{$\mathrm{Cu}$} & \multicolumn{3}{|c|}{$\mathrm{Ni}$} \\
\hline & $W_{1}$ & $W_{2}$ & $W_{3}$ & $W_{1}$ & $W_{2}$ & $W_{3}$ & $W_{1}$ & $W_{2}$ & $W_{3}$ & $W_{1}$ & $W_{2}$ & $W_{3}$ \\
\hline & \multicolumn{12}{|c|}{ Roots } \\
\hline Sakha 2 & $0.060 \mathrm{c}$ & 0700c & $0.091 \mathrm{a}$ & $7.773 \mathrm{c}$ & $10.473 d$ & $10.623 \mathrm{c}$ & $0.918 \mathrm{a}$ & $0.995 \mathrm{bc}$ & $0.997 \mathrm{c}$ & $3.163 a$ & $3.500 a$ & $3.555 b$ \\
\hline Giza 3 & $0.0638 b$ & $0.0683 \mathrm{c}$ & $0.0883 b$ & $10.793 b$ & $10.873 \mathrm{c}$ & $10.905 b$ & $8 a$ & $1.095 \mathrm{ab}$ & $1.195 b$ & $50 a$ & $460 a$ & $3.863 a$ \\
\hline Giza 843 & $0.0595 c$ & 077b & $0.0903 \mathrm{ab}$ & $11.288 a$ & $.075 a$ & $11.295 \mathrm{a}$ & $0 a$ & $0.970 c$ & $1.263 \mathrm{~b}$ & & $2.970 \mathrm{~b}$ & $3.295 b$ \\
\hline \multirow[t]{2}{*}{ Giza 461} & $0.0695 a$ & $0.0903 a$ & $0.0893 \mathrm{ab}$ & $11.558 \mathrm{c}$ & $11.300 \mathrm{a}$ & $11.075 \mathrm{ab}$ & $0.870 \mathrm{a}$ & $1.135 \mathrm{a}$ & $1.508 \mathrm{a}$ & $3.145 a$ & $2.970 \mathrm{~b}$ & $3.360 \mathrm{~b}$ \\
\hline & \multicolumn{12}{|c|}{ leaves } \\
\hline Sakha 2 & $0288 a$ & $395 a$ & 047c & $15 a$ & $3818 a$ & $1.164 a$ & C & $725 \mathrm{c}$ & $0.742 \mathrm{c}$ & $08 \mathrm{c}$ & $0.335 d$ & $.398 d$ \\
\hline Giza 3 & $0.029 \mathrm{a}$ & $398 a$ & $0.0565 b$ & $1.1185 b$ & $1.1533 b$ & 1.1 & $5 b$ & $0.880 a$ & $0.848 a$ & $0.405 b$ & $0.495 c$ & $0.453 c$ \\
\hline Giza 843 & $0.0228 \mathrm{~b}$ & $.0278 b$ & $0.0703 a$ & $0.975 c$ & $0.9662 \mathrm{c}$ & $1.1878 \mathrm{a}$ & $3 a$ & $0.883 a$ & $0.915 \mathrm{a}$ & $0.268 d$ & $0.650 a$ & $0.690 \mathrm{~b}$ \\
\hline \multirow[t]{2}{*}{ Giza 461} & $0.0148 \mathrm{c}$ & $0.0195 \mathrm{c}$ & $0.0720 a$ & $0.930 \mathrm{~d}$ & $0.9775 \mathrm{c}$ & $0.9765 b$ & 0. & $0.813 b$ & $0830 \mathrm{~h}$ & 0.453 & $0.607 \mathrm{~b}$ & $0.908 a$ \\
\hline & \multicolumn{12}{|c|}{ Seed Coat } \\
\hline Sakha 2 & $318 b$ & $95 b$ & $488 a$ & $8 b c$ & $1.080 \mathrm{c}$ & $1.1075 \mathrm{~b}$ & & $13 \mathrm{~b}$ & $648 c$ & $88 \mathrm{c}$ & $528 \mathrm{~b}$ & $.558 \mathrm{c}$ \\
\hline Giza 3 & $0413 a$ & $5 a$ & $0.04898 a$ & 0.88 & $3 \mathrm{~b}$ & & & $0.663 \mathrm{c}$ & $0.720 \mathrm{~b}$ & $58 \mathrm{~b}$ & $2.508 b$ & $2.750 \mathrm{~b}$ \\
\hline Giza 843 & $0.0373 a b$ & $0.0405 b$ & $0.0505 a$ & $0.9748 a b$ & $1.1825 \mathrm{a}$ & $1.155 \mathrm{~b}$ & $0.808 a$ & $0.837 a b$ & $0.888 a$ & $2.738 a$ & $2.88 \mathrm{~b}$ & $2.923 a$ \\
\hline \multirow[t]{2}{*}{ Giza 461} & $0.0373 a b$ & $0.0453 b$ & $0.0483 a$ & $0.9800 \mathrm{a}$ & $1.1125 \mathrm{bc}$ & $1.2368 \mathrm{a}$ & & $0.813 a b$ & $0.883 a$ & & 2.490 & $2.815 \mathrm{~b}$ \\
\hline & \multicolumn{12}{|c|}{ Pod Cover } \\
\hline Sakha 2 & $305 \mathrm{bc}$ & $2 \mathrm{c}$ & $55 \mathrm{bc}$ & & $0.8648 \mathrm{c}$ & $0.9178 \mathrm{~b}$ & & $.495 d$ & $495 d$ & $1.193 c$ & $1.725 d$ & $1.840 \mathrm{c}$ \\
\hline Giza 3 & $433 a$ & $593 b$ & $063 c$ & $.00 d$ & $0.8450 \mathrm{~d}$ & $0.8855 \mathrm{c}$ & & $.515 \mathrm{c}$ & $0.775 a$ & $1.523 b$ & $1.780 \mathrm{c}$ & $1.835 \mathrm{c}$ \\
\hline Giza 843 & $0.0430 \mathrm{a}$ & $0.0665 \mathrm{~b}$ & $0.0675 \mathrm{ab}$ & $0.8640 \mathrm{~b}$ & $0.8855 b$ & $0.8863 \mathrm{c}$ & & $0.577 \mathrm{~b}$ & $0.777 \mathrm{~b}$ & $1.873 a$ & $2.023 b$ & $2.430 \mathrm{~b}$ \\
\hline \multirow[t]{2}{*}{ Giza 461} & $0.0373 \mathrm{~b}$ & $0.0423 a$ & $0.0685 a$ & $0.9063 a$ & $0.9300 \mathrm{a}$ & $0.9920 \mathrm{a}$ & $0.580 a$ & $0.597 \mathrm{a}$ & $0.797 \mathrm{a}$ & $1.893 a$ & 2.138 & $2.675 a$ \\
\hline & \multicolumn{12}{|c|}{ Seeds ( $\mathrm{mg} / \mathrm{kg}$ ) } \\
\hline Sakha 2 & $95 a$ & $0.027 \mathrm{a}$ & $2 \mathrm{a}$ & $5 \mathrm{~d}$ & $0.360 \mathrm{c}$ & $0.375 \mathrm{~d}$ & $0.288 \mathrm{c}$ & 40c & $\overline{0 c}$ & $23 \mathrm{c}$ & $0.4475 \mathrm{c}$ & $0.4550 \mathrm{c}$ \\
\hline I & $253 \mathrm{a}$ & $0.029 \mathrm{a}$ & $04230 \mathrm{a}$ & 0.3 & $0.367 \mathrm{c}$ & $0.405 \mathrm{c}$ & & $0.413 a$ & $.448 \mathrm{a}$ & $0.4055 \mathrm{c}$ & $0.455 \mathrm{c}$ & $0.482 \mathrm{ha}$ \\
\hline Giza 843 & $0.0261 \mathrm{a}$ & $0.0295 \mathrm{a}$ & $0.03675 \mathrm{a}$ & $0.393 \mathrm{~b}$ & $0.413 \mathrm{~b}$ & $0.423 \mathrm{~b}$ & $5 a$ & $0.333 d$ & $0.348 d$ & $0.4590 \mathrm{a}$ & $0.4675 \mathrm{a}$ & $0.4775 \mathrm{~b}$ \\
\hline \multirow[t]{2}{*}{ Giza 461} & $0.0265 \mathrm{a}$ & $0.0265 \mathrm{a}$ & $0.0350 \mathrm{a}$ & $0.523 \mathrm{a}$ & $0.545 \mathrm{a}$ & $0.570 \mathrm{a}$ & $0.335 \mathrm{a}$ & $0.373 b$ & $0.416 \mathrm{~b}$ & $0.4133 \mathrm{~b}$ & $0.4475 \mathrm{c}$ & $0.4750 \mathrm{~b}$ \\
\hline & \multicolumn{12}{|c|}{${ }^{*}$ Translocation coefficient $\%$ from roots to seed } \\
\hline Sakha 2 & 39.91 & 38.57 & 42.03 & 4.31 & 3.44 & 3.53 & 31.37 & 34.17 & 39.11 & 11.49 & 14.15 & 13.98 \\
\hline Giza 3 & .70 & .45 & 48.69 & 3. & & 3. & & 37 & & 72 & 14.44 & 12.62 \\
\hline Giza 843 & 42.57 & & 40.64 & 3. & 4. & 3. & & 34.32 & 27.55 & 15.45 & 14.89 & 14.49 \\
\hline Giza 461 & 38.24 & 0 & 39.19 & 4.44 & 4.43 & 5.15 & 38.86 & 32.86 & 27.58 & 13.92 & 14.23 & 14.14 \\
\hline
\end{tabular}

